\title{
The Effect of Protein-Calorie Malnutrition on the Developing Liver
}

\author{
KAREN OPLETA, J. DECKER BUTZNER, ELDON A. SHAFFER, AND D. GRANT GALL \\ Gastrointestinal Research Group, Health Science Centre, University of Calgary, Calgary, Alberta, Canada
}

\begin{abstract}
The effects of protein-calorie malnutrition on bile salt metabolism and liver function were studied. Malnutrition was induced in rabbits by combining litters at 7 days of age (13-16 animals) and results compared to control litters (six-eight animals). At age 29-30 days biliary output from the common bile duct was measured directly for three 1-h periods: under basal conditions, and in response to intravenous infusion of exogenous glycodeoxycholic acid at 0.75 and $1.5 \mu \mathrm{mol} / \mathrm{min} / \mathrm{kg}$, respectively. The bile salt pool size was measured by isotope dilution. Final mean body weight and liver weight were significantly decreased in malnourished animals compared to controls. Liver weight/body weight was also less in the malnourished groups. Total liver DNA and protein content, as well as the protein to DNA ratio, were less in the malnourished animals compared to controls. Bile flow and bile salt secretion were reduced in the malnourished group when calculated per $\mathrm{kg}$ body weight or per mg liver DNA. Bile salt-dependent flow did not differ significantly, but bile salt-independent flow was significantly less in malnourished animals. Bile salt pool size was decreased in the malnourished group. These findings indicate that malnutrition has a greater impact on liver weight than on total body weight in the preweaning period. In addition, malnutrition reduces bile flow, bile salt secretion, and bile salt pool size which, along with the decrease in bile saltindependent flow, may reflect either an impairment of hepatic uptake function or a delay in postnatal development. (Pediatr Res 23: 505-508, 1988)
\end{abstract}

Malnourished infants exhibit malabsorption of carbohydrate, fat, and protein (1). Fat malabsorption has been attributed to: 1 ) a defect in $\beta$-lipoprotein synthesis (2);2) small bowel bacterial overgrowth and subsequent deconjugation of bile salts $(3) ; 3$ ) dilution of bile acids below the critical micellar concentration secondary to the osmotic effects of unabsorbed carbohydrates (4); and 4) pancreatic insufficiency (5). Immaturity of hepatic excretory function and bile salt metabolism further compromises fat absorption in the infant $(6,7)$. During infancy the bile salt pool size is reduced, synthetic rate depressed, and active ileal transport deficient $(8-10)$. In infant rabbits bile flow and bile salt output are reduced, but gradually increase to near adult levels at the time of weaning (11).

Although bile acids play an important role in the absorption of fat from the intestine, the impact of chronic malnutrition on bile flow and bile salt secretion has not been defined. Herein we

Received June 22, 1987; accepted January 12, 1988.

Correspondance and reprints D. Grant Gall, M.D., Department of Pediatrics, Health Science Centre, 3330 Hospital Drive N.W., Calgary, Alberta. T2N 4N1, Canada.

Supported by grants from the Medical Research Council of Canada and The Canadian Foundation for Ileitis and Colitis. examine how malnutrition initiated early in life effects the developing liver and biliary excretory function.

\section{METHODS}

Animal model. Suckling New Zealand White rabbits were studied. Protein-calorie malnutrition was induced by combining litters at 7 days of age for a final litter size of 13 to 16 animals $(n=11)$. The expanded litter was then alternated between the two does at 24-h intervals. This ensured maternal health, allowed does to feed on alternate days, and prevented the infants from having access to solid food. Control litters were derived by combining two litters and then reducing litter size to six to eight animals $(n=8)$. Control litters were also alternated between two does, but were allowed access to food. Animals were weighed on alternate days and studied at 28-30 days. Twelve $h$ before the bile output studies $0.3 \mu \mathrm{Ci}$ of ${ }^{14} \mathrm{C}$-cholic acid (New England Nuclear, Boston, MA) was injected intravenously to label the bile salt pool. Serum was taken from littermates also injected with ${ }^{14} \mathrm{C}$-cholic acid $12 \mathrm{~h}$ after injection in order to determine if the cholic acid had been cleared from the blood.

Experimental procedure. Under halothane anaesthetic, the cystic duct was ligated and the common duct cannulated with PE 50 polyethylene tubing. Bile was collected directly into tarred tubes at 30-min intervals and the volume determined gravimetrically assuming a density of $1.0 \mathrm{~g} / \mathrm{ml}$. Samples were then frozen at $-70^{\circ} \mathrm{C}$ for later analysis. The first $60 \mathrm{~min}$ of bile output was disregarded to allow steady state conditions to become established (12). Three 1-h study periods followed: a basal period plus two in which exogenous bile acid was infused. Glycodeoxycholic acid (Calbiochem,-Behring, La Jolla, CA), the major bile acid in rabbits (13), was infused at 0.75 and then $1.5 \mu \mathrm{mol} / \mathrm{min} / \mathrm{kg}$, respectively. In each of these three $1-\mathrm{h}$ periods the final $30 \mathrm{~min}$ was used to determine bile flow and bile salt secretion. The initial $30 \mathrm{~min}$ was disregarded in order to allow steady state conditions to develop and to eliminate the dead space in the biliary tree and collection cannula. Solutions, $154 \mathrm{mM} \mathrm{NaCl}$ with or without exogenous bile acid, were infused intracardiac at a rate of 0.1 $\mathrm{ml} / \mathrm{min} / \mathrm{kg}$. In addition, the volume of bile collected was replaced continuously with $154 \mathrm{mM} \mathrm{NaCl}$. After the bile output studies the liver was removed, weighed, sections obtained for morphology, and the remainder homogenized in $2.5 \mathrm{mM}$ EDTA for later determination of protein and DNA content. Liver specimens for light microscopy were fixed in $10 \%$ buffered formalin and sections stained with hematoxylin and eosin. Serum was obtained for determination of total protein.

Analytical methods. Bile salt concentration was measured enzymatically (14) and bile salt pool determined according to the modified isotope-dilution technique of Meyer and Denbesten (15). Preliminary experiments were carried out comparing the wash-out technique of Myant and Eder (16) to the modified isotope-dilution technique of Meyer and Denbesten (15) in rabbits of this age group. Results obtained closely parallel those of Meyer and Denbesten (15) in that the isotope-dilution technique 
corresponded closely (range $92-105 \%$ ) to the wash-out method of measuring pool size. The isotope-dilution method was therefore used for measuring bile salt pool in this animal model. Liver homogenate and serum were assayed for protein by the method of Lowry et al. (17) and hepatic DNA by the method of Hinegardner (18).

Results are expressed as mean \pm SE. Student's $t$ test or paired $t$ test, where appropriate, were applied to evaluate differences between the means. Slopes and intercepts of the regression lines were compared by analysis of covariance (19).

\section{RESULTS}

Body weight and clinical data. Initial mean body weights in the control and malnourished groups were similar when the litters were combined on day $7(129 \pm 15 ; 123 \pm 22 \mathrm{~g})$. By 18 days of age, mean cumulative weight gain of the undernourished animals was significantly less than control values (Fig. 1). This difference persisted thereafter and by 28 days of age, mean body weight of the undernourished animals was only $47 \%$ of controls (Fig. 2). However, all animals appeared clinically healthy and total serum protein did not differ between the control $(51 \pm 3 \mathrm{~g}$ / liter) and malnourished $(55 \pm 2)$ groups. There was no evidence of radiolabeled cholic acid in the serum of either controls or malnourished, indicating that both groups had effectively cleared the cholic acid into the bile salt pool before the start of the bile flow experiments.

Liver weight, protein, DNA, and morphology. Liver weight, whether expressed as absolute total weight or liver weight/body weight, was significantly depressed in the malnourished group compared to controls (Fig. 2). The reduced liver weight in the malnourished animals was associated with a significant decrease in total hepatic DNA and protein (Fig. 3). The protein to DNA ratio was also significantly reduced in the malnourished compared to control animals (Fig. 3). Histologic sections of liver from the two groups were indistinguishable; specifically there was no evidence of hepatocellular necrosis or fatty infiltration.

Bile salt secretion and pool size. Bile salt secretion was significantly less in the malnourished group in the basal period and in response to glycodeoxycholic acid infusion compared to control values when expressed per body weight (Table 1a). When the values were expressed per liver DNA (Table $1 \mathrm{~b}$ ), these differences
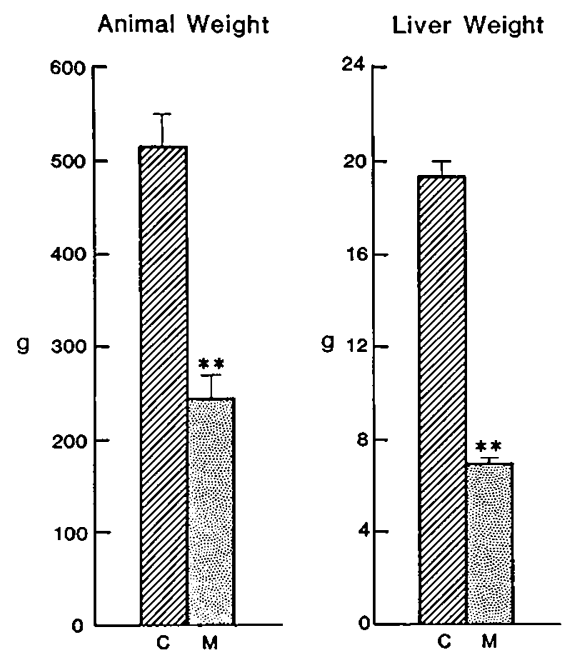

Liver Wt./Body Wt.

Fig. 2. Total body weight, liver weight, and liver/body weight in control $(C)$ and malnourished $(M)$ animals. Values are means $\pm \mathrm{SE}$.
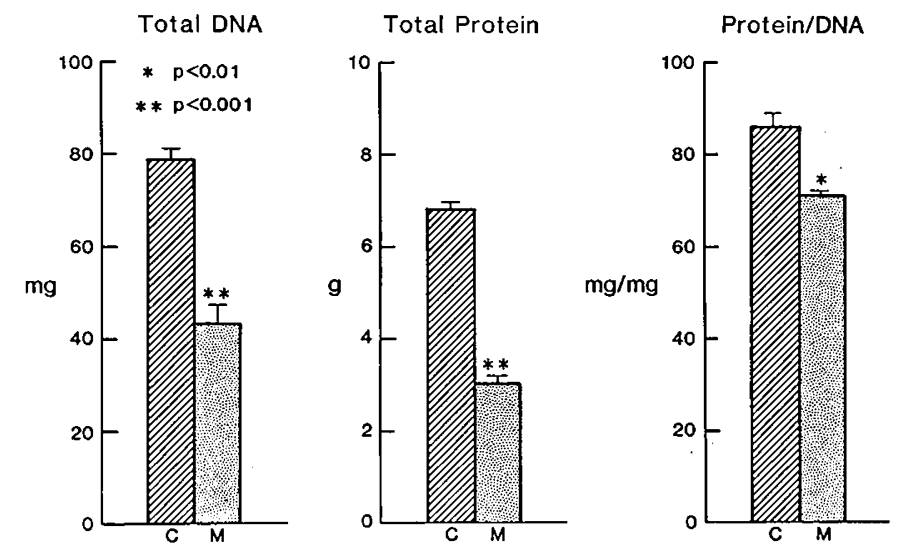

Fig. 3. Total DNA, total protein, and protein/DNA in control $(C)$ and malnourished $(M)$ animals. Values are means $\pm \mathrm{SE}$.

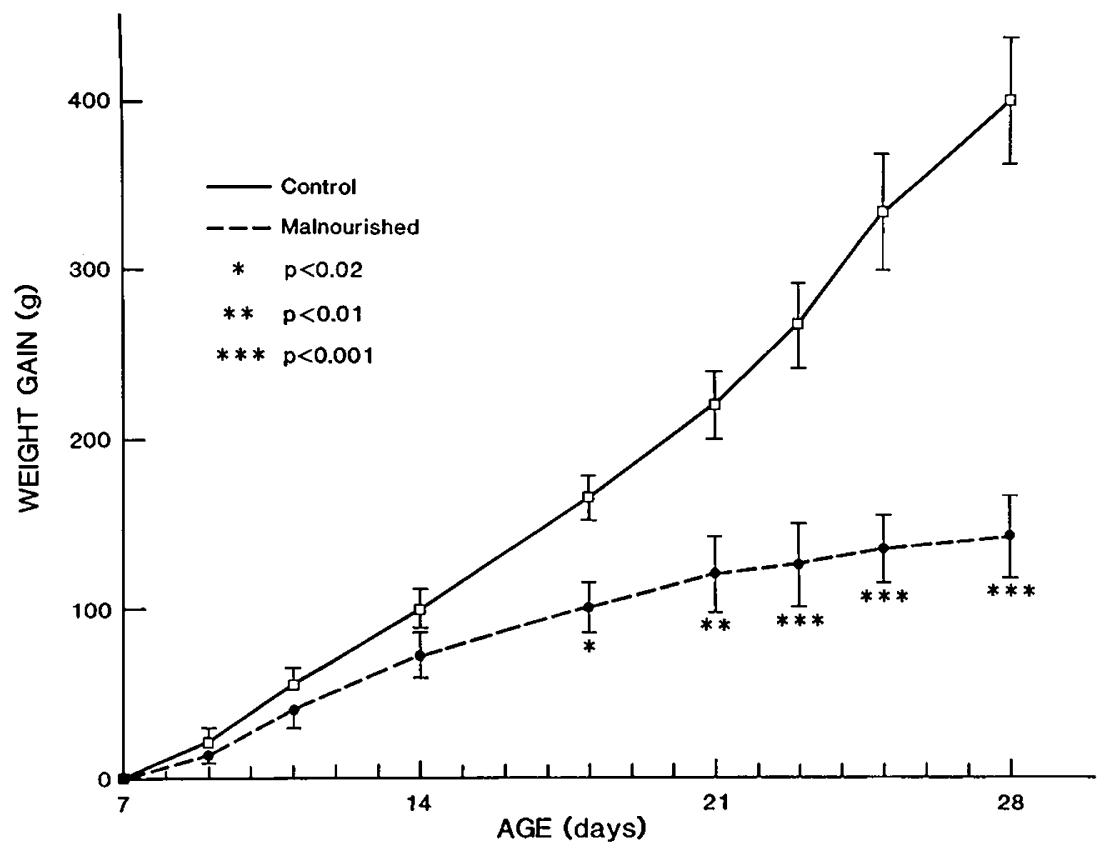

Fig. 1. Cumulative weight gain of control and malnourished animals. Values are means $\pm S E$. 
Table 1. Bile salt secretion*

\begin{tabular}{cccc}
\hline $\begin{array}{c}\text { Bile acid infusion } \\
\text { rate } \dagger\end{array}$ & \multicolumn{1}{c}{0} & 0.75 & $\begin{array}{c}1.5 \mu \mathrm{mol} / \\
\mathrm{min} / \mathrm{kg}\end{array}$ \\
\hline (a) Control & $0.708 \pm 0.08$ & $1.701 \pm 0.16$ & $2.487 \pm 0.4$ \\
Malnourished & $0.538 \pm 0.05 \ddagger$ & $0.922 \pm 0.11 \S$ & $1.505 \pm 0.1 \S$ \\
& & & \\
(b) Control & $4.86 \pm 0.6$ & $11.83 \pm 1.4$ & $17.43 \pm 2.9$ \\
Malnourished & $3.53 \pm 0.4 \ddagger$ & $6.96 \pm 0.6 \S$ & $9.60 \pm 0.9 \S$ \\
\hline
\end{tabular}

* Values are expressed as mean $\pm \mathrm{SE} \mu \mathrm{mol} / \mathrm{min} / \mathrm{kg}$ body weight in (a) or as $\mathrm{nmol} / \mathrm{min} / \mathrm{mg}$ hepatic DNA in (b) during $1 \mathrm{st} h$ (basal period) and subsequent $2 \mathrm{~h}$ of exogenous bile acid infusion.

$\dagger$ Infusion rate of glycodeoxycholic acid in $\mu \mathrm{mol} / \mathrm{min} / \mathrm{kg}$ body weight. $\ddagger p<0.05$ compared to control.

$\S p<0.01$ compared to control.

Table 2. Bile flow*

\begin{tabular}{cccc}
\hline $\begin{array}{c}\text { Bile acid infusion } \\
\text { rate } \dagger\end{array}$ & \multicolumn{1}{c}{0} & \multicolumn{1}{c}{0.75} & \multicolumn{1}{c}{1.5} \\
\hline (a) Control & $87.1 \pm 6$ & $133.1 \pm 11$ & $169.4 \pm 21$ \\
Malnourished & $57.9 \pm 4 \ddagger$ & $81.4 \pm 4 \ddagger$ & $101.8 \pm 5 \ddagger$ \\
& & & \\
(b) Control & $0.579 \pm 0.03$ & $0.909 \pm 0.07$ & $1.159 \pm 0.15$ \\
$\quad$ Malnourished & $0.387 \pm 0.04 \ddagger$ & $0.552 \pm 0.06 \ddagger$ & $0.696 \pm 0.06 \ddagger$ \\
\hline
\end{tabular}

* Values are expressed as mean $\pm \mathrm{SE} \mu \mathrm{l} / \mathrm{min} / \mathrm{kg}$ body weight in (a) or as $\mu \mathrm{l} / \mathrm{min} / \mathrm{mg}$ hepatic DNA in (b) during 1st $\mathrm{h}$ (basal period) and subsequent $2 \mathrm{~h}$ of exogenous bile acid infusion.

$\dagger$ Infusion rate of glycodeoxycholic acid in $\mu \mathrm{mol} / \mathrm{min} / \mathrm{kg}$ body weight. $\ddagger p<0.001$.

remained significantly different. Malnutrition also led to a contracted bile salt pool ( $212 \pm 46 \mu \mathrm{mol})$ compared to controls (394 $\pm 51, p<0.05$ ).

Bile flow. A significant decrease in bile flow in the malnourished animals accompanied the decrease in bile salt secretion. Bile flow was significantly reduced under basal conditions and in response to administration of glycodeoxycholic acid in the malnourished rabbits compared to controls, whether expressed per body weight (Table 2a) or per liver DNA (Table 2b). In each group, bile flow increased significantly $(p<0.005)$ with endogenous administration of 0.75 and $1.5 \mu \mathrm{mol} / \mathrm{min} / \mathrm{kg}$ glycodeoxycholic acid.

Bile flow vs bile salt secretion. There was a linear correlation between bile flow and bile salt secretion rate in both the malnourished and control groups (Fig. 4). Bile salt-dependent flow, defined as the increment in flow per quantity of bile salt secreted ( $\mu \mathrm{l}$ flow $/ \mu \mathrm{mol}$ bile salt) and represented by the slope of the linear relationship, was not altered by malnutrition. Bile salt-independent flow, as assessed by extrapolation of the linear relationship to a theoretical zero bile salt secretion, the y-axis intercept, was significantly reduced in the malnourished group.

\section{DISCUSSION}

Our results indicate that chronic malnutrition has a marked adverse effect on the developing liver which results in decreased growth and impaired bile formation.

In rabbits, the amount of breast milk available from the mother varies and is fixed by the size of the litter (20). By combining litters at 7 days of age, we achieved restriction of caloric intake. This resulted in a clinical state of severe protein-calorie malnutrition, defined as body weight less than $60 \%$ of that expected for age and absence of edema and normal serum protein levels (21).

In the malnourished animals, both body weight and liver wet weight were significantly depressed compared to controls. When liver weight was expressed as percentage of body weight, liver weight remained significantly depressed compared to controls,

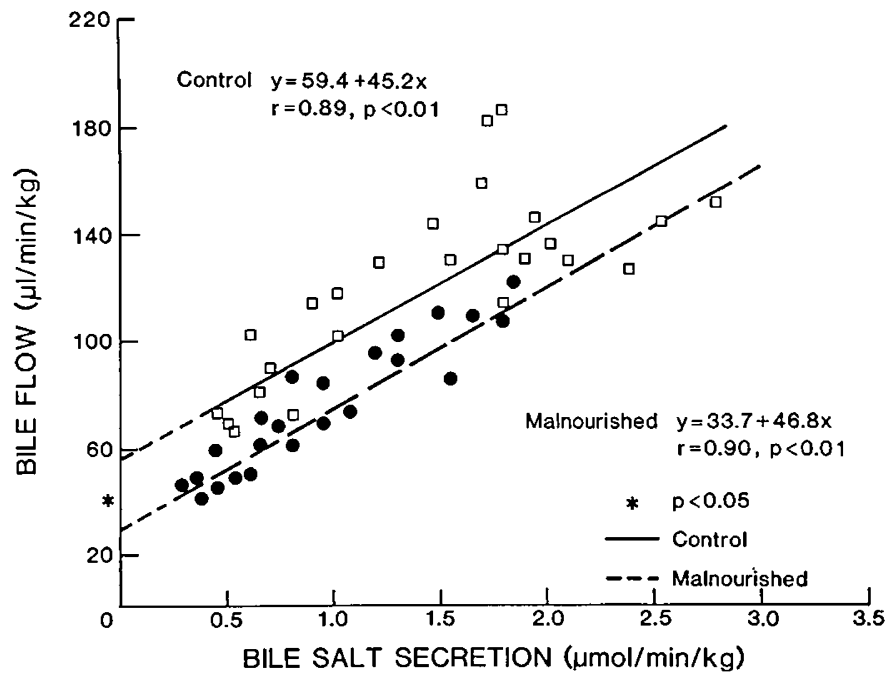

Fig. 4. Bile flow vs bile salt secretion per body weight in controls (squares) and malnourished (circles) animals. Slope of the line represents bile salt-dependent flow whereas the extrapolated y-intercept represents bile-salt independent flow.

indicating that the impact of malnutrition on liver growth is more severe than on overall body growth. The decrease in liver weight was due to both a decrease in cell number, as reflected by the decrease in total DNA, and a decrease in cell size, as reflected by the decrease in protein to DNA ratio. These results correspond closely to those seen by Widdowson and McCance (22) in slow growing rats.

Malnourished animals exhibited a severe reduction in bile salt secretion which resulted in a decrease in total bile flow. Formation of bile in the canaliculus has been theoretically divided into two components: bile salt-dependent flow and bile salt-independent flow. Bile salt-dependent flow is the volume of water excreted per increment in bile salt secretion and represents the choleretic potential of that bile salt (23). Bile salt-independent flow represents the theoretical flow which might continue if bile salt secretion were absent (24). The measurement of bile flow at zero bile salt secretion is not possible due to continuous hepatic synthesis of bile salts, but bile salt-independent flow can be estimated by extrapolating the linear relation of bile flow to bile salt secretion to the y-axis. Despite concern that this relation may not remain linear at very low, near zero, bile salt secretion rates, the concept remains in use. Indeed, this portion of bile flow may relate to the secretion of organic solute other than bile salts. Active secretion of organic anions such as glutathione and its metabolites may be responsible for this aspect of bile flow (25). Malnutrition in infant animals reduced the bile salt-independent component of bile flow. This may represent a reduction in synthesis and secretion of the organic acids responsible for this component of bile output. Although bile salt-dependent flow, as represented by the increment of flow per unit of bile salt secreted, was not different in the two groups, total bile flow was reduced in the malnourished group due to reduced bile salt secretion.

The alterations in hepatic function induced by malnutrition may be due, in part, to an impaired uptake of bile acids by the hepatocyte sinusoidal membrane. The uptake of bile acids is a carrier-mediated active sodium dependent cotransport process (24). The decrease in protein synthesis seen in the malnourished animals, along with the reduction in total cell number, could possibly decrease the total number of bile acid receptors in the liver and decrease cellular uptake.

Malnutrition in infant animals may also cause a delay in the normal maturation of the liver. In infants, many aspects of liver function are not fully developed. Bile salt synthesis and total bile salt pool size are reduced (8) and active ileal transport is deficient 
(26). In addition, bile flow and bile salt output are reduced in early life and gradually increase to near adult levels by the time of weaning (11). The increase in bile output during the postnatal period is associated with increased bile salt secretion and the appearance of bile salt-independent flow. Hepatic function in the undernourished animals exhibited a number of features compatible with a delay in postnatal maturation. Bile output was reduced in the malnourished animals because of decreased bile salt secretion and decreased bile salt-independent flow. Further, the pool size was reduced.

The decrease in bile salt secretion and smaller pool size could also be the result of decreased hepatic synthesis and/or reduced intestinal absorption. Reduced hepatic bile salt synthesis is a likely contributing factor because liver size and cellularity were decreased by malnutrition. Malnutrition in suckling rabbits has been shown to reduce small intestinal growth and maturation (27). Reduced ileal uptake of bile salts could be secondary to a decrease in ileal epithelial mass, i.e. enterocyte number, or to a delay in postnatal development of active transport in the ileum. Bacterial overgrowth of the small intestine seems unlikely as a major cause of decreased bile acid absorption. In experiments examining the impact of malnutrition on the intestine we demonstrated decreased crypt-villus length and increased lactase activity whereas net $\mathrm{Na}^{+}$transport was not altered in malnourished animals (27). In contrast, in bacterial overgrowth there is hypertrophy of crypts and villi (28), decreased disaccharidases (29), and impaired $\mathrm{Na}^{+}$and $\mathrm{Cl}^{-}$transport (30). Furthermore, bacterial overgrowth has not been shown to be cholestatic although bacterial modification of bile acids occur. In fact, experimentally, bacterial overgrowth leads to increased bile salt secretion and bile flow due to a short-circuit via a jejunohepatic shunt (31).

In summary, protein-calorie malnutrition appears to have a severe impact on the developing liver as shown by decreased growth, reduced bile salt pool size, and decreased bile output.

\section{REFERENCES}

1. James WPT 1971 Effects of protein-calorie malnutrition on intestinal absorption. Ann NY Acad Sci 176:244-261

2. Isselbacher KJ, Budz D 1963 Synthesis of lipoproteins by rat intestinal mucosa. Nature 200:364-365

3.' Schneider RE, Viteri F 1974 Luminal events of lipid absorption in proteincalorie malnourished children: relationships with nutritional recovery and diarrhea. I. Capacity of the duodenal content to achieve micellar solubilization in lipids. Am J Clin Nutr 27:777-787

4. Ringrose RE, Thompson JB, Welsh JD 1972 Lactose malabsorption and steatorrhea. Am J Dig Dis 17:533-538

5. Barbezat GO, Hansen JDL 1968 The exocrine pancreas and protein-calorie malnutrition. Pediatrics 42:77-92
6. Lester R 1980 Physiologic cholestasis. Gastroenterology 78:864-870

7. Henning SJ 1981 Postnatal development: coordination of feeding, digestion and metabolism. Am J Physiol 241:G199-G214

8. Watkins JB, Ingall D, Szczepanik P, Klein PD, Lester R 1973 Bile salt metabolism in the newborn. Measurement of pool size and synthesis by stable isotope technique. N Engl J Med 288:431-434

9. Huebi JE, Fondacaro JD 1982 Postnatal development of intestinal bile salt transport in the guinea pig. Am J Physiol 243:G189-G194

10. Belknap WM, Balistreri WF, Suchy FJ, Miller PC 1981 Physiologic cholestasis. II: Serum bile acid levels reflect the development of the enterohepatic circulation in rats. Hepatology 1:613-615

11. Shaffer EA, Zahavi I, Gall DG 1985 Postnatal development of hepatic bile formation in the rabbit. Dig Dis Sci 30:558-563

12. Klassen C 1974 Bile flow and composition during bile acid depletion and administration. Can J Physiol Pharmacol 52:334-338

13. Lindstedt S, Sjoval S 1957 On the formation of deoxycholic acid from cholic acid in the rabbit. Acta Chem Scand [B] 11:421-426

14. Shaffer EA, Small DM 1977 Biliary lipid secretion in cholesterol gallstone disease. The effect of cholecystectomy and obesity. J Clin Invest 59:828-840

15. Meyer P, Denbesten L 1977 A comparison of methods for bile salt pool size measurements in the prairie dog gallstone model. Proc Soc Exp Biol 156:452456

16. Myant NB, Eder HA 1961 The effect of biliary drainage upon the synthesis of cholesterol in the liver. J Lipid Res 2:363-368

17. Lowry OH, Rosebrough NH, Farr AL, Randall RJ 1951 Protein measurement with the Folin phenol reagent. J Biol Chem 193:265-275

18. Hinegardner R 1971 An improved fluorometric assay for DNA. Anal Biochem 329:197-201

19. Kleinbaum D, Kupper L 1978 Applied Regression Analysis and other Multivariable Methods. Duxbury Press, Boston, pp 438-44

20. Hagen KW 1974 Colony Husbandry. In: Wersbroth S, Flatt A, Kraus A (eds) Biology of the Laboratory Rabbit. Academic Press, New York, pp 23-45

21. Suskind RM 1975 Gastrointestinal changes in the malnourished child. Pediatr Clin North Am 22:873-883

22. Widdowson EM, McCance RA 1960 Some effects of accelerating growth and general somatic development. Proc Roy Soc 152:188-206

23. Forker EL 1977 Mechanisms of hepatic bile formation. Ann Rev Physiol 39:323-347

24. Erlinger SD, Dhumeuz D, Bertlelot P, Dumont M 1970 Effects of inhibitors of sodium transport on bile formation in the rabbit. Am J Physiol 219:416422

25. Graf J 1983 Canalicular bile salt-independent bile formation: concepts and clues from electrolyte transport in rat liver. Am J Physiol 244:G233-246

26. deBelle RC, Vauphas V, Bitullo B, Haber LR, Shaffer EA, Mackie GG, Owen H, Little JM, Lester R 1979 Intestinal absorption of bile salts: immature development in the neonate. J Pediatr 94:472-476

27. Butzner JD, Gall DG Impact of protein-caloric malnutrition on the developing intestine: a model in young rabbits. Biol Neonate (in press)

28. Toskes PP, Giannella RA, Jervis HR, Rout WR, Takeuchi A 1975 Small intestinal mucosal injury in the experimental blind loop syndrome. Gastroenterology 68:1193-1203

29. Jonas A, Flanagan PR, Forstner GG 1977 Pathogenesis of mucosal injury in the blind loop syndrome. Brush border enzyme activity and glycoprotein degradation. J Clin Invest 60:1321-1330

30. Schulzke JD, Fromm M, Menge H, Riecken ED 1987 Impaired intestinal sodium and chloride transport in the blind loop syndrome of the rat. Gastroenterology 92:693-8

31. Bender S, Sauer H, Hoffmann D 1975 Kinetics of bile acid metabolism in experimental blind loop syndrome. Gut 16:927-931 